\title{
Comparison of Ethylene Production by Pseudomonas syringae and Ralstonia solanacearum
}

\author{
H. Weingart, B. Völksch, and M. S. Ullrich
}

First and second authors: Friedrich-Schiller-University Jena, Institute of Microbiology, Philosophenweg 12, 07743 Jena, Germany; and third author: Max-Planck-Institute of Terrestrial Microbiology, Karl-von-Frisch-Strasse, 35043 Marburg, Germany.

Accepted for publication 3 February 1999.

\begin{abstract}
Weingart, H., Völksch, B., and Ullrich, M. S. 1999. Comparison of ethylene production by Pseudomonas syringae and Ralstonia solanacearum. Phytopathology 89:360-365.

Strains of Pseudomonas syringae pv. pisi and Ralstonia solanacearum produced ethylene at rates 20- and 200-fold lower, respectively, than strains of $P$. syringae pvs. cannabina, glycinea, phaseolicola, and sesami. In the current study, we investigated which ethylene biosynthetic pathways were used by $P$. syringae pv. pisi and $R$. solanacearum. Neither the activity of an ethylene-forming enzyme nor a corresponding efe gene homolog could be detected in $R$. solanacearum, suggesting synthesis of ethylene via 2keto-4-methyl-thiobutyric acid. In contrast, 2-oxoglutarate-dependent ethyl-

ene formation was observed with $P$. syringae pv. pisi, and Southern blot hybridization revealed the presence of an efe homolog in this pathovar. The efe genes from $P$. syringae pvs. cannabina, glycinea, phaseolicola, pisi, and sesami were sequenced. Nucleotide sequence comparisons indicated that the efe gene in pv. pisi was not as highly conserved as it was in other P. syringae pathovars. The pv. pisi efe homolog showed numerous nucleotide substitutions and a deletion of 13 amino acids at the C-terminus of the predicted gene product. These sequence alterations might account for the lower rate of ethylene production by this pathovar. All ethyleneproducing $P$. syringae pathovars were virulent on bush bean plants. The overlapping host range of these pathovars suggests that horizontal transfer of the efe gene may have occurred among bacteria inhabiting the same host.
\end{abstract}

Among plant-pathogenic bacteria, Ralstonia (formerly Pseudomonas or Burkholderia) solanacearum has long been known to produce ethylene gas (3). However, the most efficient bacterial ethylene producers belong to the $P$. syringae group. Goto et al. (9) found that strains of $P$. syringae pv. phaseolicola, which are pathogenic to the Japanese weed Pueraria lobata (Willd.) Ohwi (common name: kudzu), form large amounts of ethylene. Strains of $P$. syringae pvs. cannabina, glycinea, and sesami also produce ethylene as efficiently as the pv. phaseolicola kudzu strains $(21,22)$. In contrast, $P$. syringae pv. pisi strains showed a 20 -fold lower ethylene production rate than the other pathovars (30). Recently, we demonstrated that strains of $P$. syringae pvs. glycinea and phaseolicola were also able to produce ethylene in planta, suggesting a role for ethylene in pathogenicity (30).

Microbial ethylene biosynthesis can occur via two different routes. Both pathways are distinct from that of higher plants, which use only one pathway involving 1-aminocyclopropane-1-carboxylic acid as the sole intermediate (12). Most microorganisms produce only trace amounts of ethylene via the 2-keto-4-methyl-thiobutyric acid (KMBA) pathway (13). KMBA is a transaminated derivative of methionine. In this pathway, a NADH:Fe(III)EDTA oxidoreductase catalyzes the formation of hydroxyl radicals from molecular oxygen (7). The hydroxyl radicals serve as oxidizing agents in the nonenzymatic oxidation of KMBA to ethylene, methanethiol, and carbon dioxide (19).

The precursor for the second pathway is 2-oxoglutarate. Four pathovars of $P$. syringae and the fungi Penicillium digitatum, Penicillium cyclopium, Chaetomium globosum, Phycomyces nitens, and Fusarium oxysporum have been reported to produce ethylene in a 2-oxoglutarate-dependent manner $(5,22)$. A single protein, the

Corresponding author: M. S. Ullrich

E-mail address: ullrichm@mailer.uni-marburg.de

Publication no. P-1999-0304-03R

(C) 1999 The American Phytopathological Society ethylene-forming enzyme (EFE), was found to be responsible for the ethylene formation by these microorganisms. The EFE of $P$. syringae pv. phaseolicola has been characterized extensively $(4,6$, 14,15,17).

The EFE protein is a member of the superfamily of $\mathrm{Fe}^{2+} /$ ascorbate oxidases $(4,5)$. It is encoded by the efe gene located on one of the indigenous plasmids of $P$. syringae $(16,22,29)$. Two reactions are simultaneously catalyzed by the EFE. In the main reaction, 2oxoglutarate is dioxygenated to produce one molecule of ethylene and three molecules of carbon dioxide. In the second reaction, both 2-oxoglutarate and L-arginine are monooxygenated. The end products of the subreaction are succinate, carbon dioxide, guanidine, and L- $\Delta^{1}$-pyrroline-5-carboxylate (6). Ethylene and succinate are formed in a molar ratio of 2:1.

In this paper, we provide evidence that $P$. syringae pv. pisi strains belong to the group of 2-oxoglutarate-dependent ethylene producers. In contrast, EFE activity could not be detected in tested $R$. solanacearum strains, indicating that ethylene formation by these bacteria probably occurs via the KMBA pathway. The EFE encoding genes from five ethylene-forming $P$. syringae pathovars were sequenced. Sequence alignment revealed a high conservation of the efe gene among $P$. syringae pvs. cannabina, glycinea, phaseolicola, and sesami, whereas numerous differences were found in the nucleotide sequence of the efe gene from a low ethylene-producing strain of $P$. syringae pv. pisi. Using a polymerase chain reaction (PCR)-based approach, these differences were also found in four other strains of pv. pisi and may explain why this pathovar produces less ethylene.

\section{MATERIALS AND METHODS}

Bacterial strains and growth conditions. The bacterial strains used in this study are described in Table 1. Pseudomonas strains were routinely cultured on bouillon glycerol agar $(26)$ at $28^{\circ} \mathrm{C}$. The references cited in Table 1 indicate the specific studies or laboratories in which the strains were isolated and characterized. 
Determination of ethylene production and bacterial growth. Ethylene production and bacterial growth curves were determined in 5a medium (26) using 100-ml cultures in 500-ml flasks shaken at $140 \mathrm{rpm}$ and incubated at $28^{\circ} \mathrm{C}$. At the appropriate time points, $1 \mathrm{ml}$ of the culture was transferred to a sterile 5-ml syringe sealed with a rubber cap and incubated on a rotary shaker at $90 \mathrm{rpm}$ for $2 \mathrm{~h}$ at $28^{\circ} \mathrm{C}$. After incubation, 1-ml gas samples were withdrawn using a gas-tight syringe, and ethylene was determined with a GC-14A gas chromatograph (Shimadzu Scientific Instruments, Inc., Duisburg, Germany) equipped with an active aluminum column and a flame ionization detector. Ethylene was determined every $3 \mathrm{~h}$, and production rate was expressed in nanoliters per hour per cell. Bacterial growth was estimated by the optical density of the bacterial cultures at $578 \mathrm{~nm}$ using a spectrophotometer. Strains of eight previously unexamined $P$. syringae pathovars, avellanae, dendropanices, garcae, hibisci, mellea, myricae, porri, and zizaniae, were tested for their ability to produce ethylene.

Ethylene production by cell-free protein extracts. For the preparation of cell-free protein extracts, $100 \mathrm{ml}$ of an overnight culture in 5a medium (26) was centrifuged at $8,000 \times g$ for $15 \mathrm{~min}$. Cells were washed twice with deionized water, resuspended in $5 \mathrm{ml}$ of $10 \mathrm{mM}$ phosphate buffer ( $\mathrm{pH} 7.0$ ), and disrupted by sonicating five times for $30 \mathrm{~s}$ with a cooling time of 1 min between bursts of sonication. Vials were immersed in an ice-water/acetone mixture during sonication. Cell debris was removed by centrifugation at $20,000 \times g$ at $4^{\circ} \mathrm{C}$ for $30 \mathrm{~min}$, and the supernatant was used as cell-free protein extract.

Ethylene production was determined using a reaction mixture $(2 \mathrm{ml})$ that contained $0.4 \mathrm{ml}$ of $200 \mathrm{mM} \mathrm{N}$-2-hydroxyethylpiperazine- $N^{\prime}$ 2-ethanesulfonic acid/NaOH buffer ( $\mathrm{pH} 8.0$ ), $0.2 \mathrm{ml}$ of $0.75 \mathrm{mM}$ $\mathrm{FeSO}_{4}, 0.2 \mathrm{ml}$ of $10 \mathrm{mM}$ dithiothreitol, $0.2 \mathrm{ml}$ of $10 \mathrm{mM} \mathrm{L}-$ arginine, $0.2 \mathrm{ml}$ of $100 \mathrm{mM}$ L-histidine, $0.2 \mathrm{ml}$ of $10 \mathrm{mM}$ 2-oxoglutarate, $0.4 \mathrm{ml}$ of deionized water, and $0.2 \mathrm{ml}$ of cell-free extract $(8,13,14)$. Test tubes $(12-\mathrm{ml}$ capacity) containing $2 \mathrm{ml}$ of the reaction mixture were sealed with rubber caps and incubated on a rotary shaker at $140 \mathrm{rpm}$ for $1 \mathrm{~h}$ at $28^{\circ} \mathrm{C}$. After incubation, a 1-ml gas sample was withdrawn using a gas-tight syringe, and ethylene was determined with a gas chromatograph as described above. The protein concentration of the cell-free extract was measured by the Bradford method (20). Ethylene production rate was expressed as nanoliters per hour per milligram of protein.

Southern blot analysis. Southern blots were performed as described by Sambrook et al. (20) using a digoxigenin (DIG) DNA labeling and luminescent detection kit (Boehringer-Mannheim, Mannheim, Germany). A DIG-labeled DNA probe was prepared from a PCR amplification product carrying the efe gene from $P$. syringae pv. phaseolicola PK2. Hybridizations were carried out with a hybridization temperature of $60^{\circ} \mathrm{C}$ and two 10 -min washes with $0.1 \times$ $\mathrm{SSC}(1 \times \mathrm{SSC}$ is $0.15 \mathrm{M} \mathrm{NaCl}$ plus $0.015 \mathrm{M}$ sodium citrate) and $0.1 \%$ sodium dodecyl sulfate at $60^{\circ} \mathrm{C}$.

PCR analysis. Two 18-mer oligonucleotides with the sequences 5'-GTCACCAGTAACGATAAG-3' (primer EFE11) and 5'-TATGGATAAAGAAGAGAC-3' (primer EFE12) were chosen for amplification of the genes encoding the EFE of different $P$. syringae pathovars. These primers were located $55 \mathrm{bp}$ upstream and $22 \mathrm{bp}$ downstream, respectively, of the efe open reading frame. For $P$. syringae pv. pisi, primer EFE11 was used together with primer ZR2 (5'-CTGCGATGAAAAAGT-3') complementary to a nucleotide sequence from within a transposase gene that has been found on plasmid $\mathrm{p} 4180 \mathrm{~A}$ and other plasmids of $P$. syringae pv. glycinea PG4180 (25; M. Ullrich and C. L. Bender, unpublished data). Since the efe gene has been reported to reside on plasmids $(16,22,29)$, use of this nucleotide primer was intended to obtain a PCR fragment containing the efe and transposase genes to facilitate nucleotide sequencing. Three additional primers were designed based on the efe sequence of $P$. syringae pv. pisi GSPB1206 to determine a possible conservation of nucleotide substitutions among other strains of this pathovar. The sequence of primer EFEP1 (5'-
ACGCTGGGATGTTACTTG-3') was complementary to nucleotides 1,012 to 1,029 of the sequence published in GenBank submission AF101061 (efe gene of $P$. syringae pv. pisi GSPB1206), whereas primer EFEP2 (5'-GCCTGTTCAAAACGTGTG-3') was identical to nucleotides 727 to 744 of AF101061. The sequence of oligonucleotide primer EFEP3 (5'-GAGGTTATTGGCAGCGCC-3') was identical to nucleotides 38 to 55 from AF101061. The standard reaction mixture $(50 \mu \mathrm{l})$ contained $10 \times$ PCR reaction buffer (Qiagen, Hilden, Germany), $2 \mathrm{mM} \mathrm{MgCl}_{2}, 0.2 \mathrm{mM}$ each of dNTPs, 1 unit Taq DNA polymerase (Qiagen), $25 \mathrm{pmol}$ of each primer, and $50 \mathrm{ng}$ of DNA. Amplification included initial denaturation $\left(95^{\circ} \mathrm{C}\right.$ for $\left.3 \mathrm{~min}\right)$; followed by 30 cycles of denaturation $\left(94^{\circ} \mathrm{C}\right.$ for $\left.1 \mathrm{~min}\right)$, annealing $\left(60^{\circ} \mathrm{C}\right.$ for $\left.1 \mathrm{~min}\right)$, and extension $\left(72^{\circ} \mathrm{C}\right.$ for $\left.1 \mathrm{~min}\right)$; and a single final extension $\left(72^{\circ} \mathrm{C}\right.$ for $\left.10 \mathrm{~min}\right)$. PCRs were carried out with a GenAmp 2400 thermocycler (Perkin-Elmer, Foster City, CA).

DNA sequencing. Nucleotide sequencing of PCR-generated DNA fragments for both strands was performed by the dideoxynucleotide method (20) with the Thermo Sequenase fluorescent-labeled primer cycle sequencing kit (Amersham-Buchler, Braunschweig, Germany). Automated DNA sequencing was accomplished with an ALF Express sequencing apparatus (Pharmacia, Freiburg, Germany). Sequence data were aligned and processed with the Lasergene version 4.1 software package (DNASTAR Inc., Madison, WI).

Pathogenicity tests. Plants were grown in individual pots in a greenhouse at 20 to $30^{\circ} \mathrm{C}$ with supplemental light for a 14-h photoperiod. Bush bean plants (Phaseolus vulgaris L. cv. Red Kidney) were inoculated by spraying the abaxial surfaces of leaves using a glass atomizer until water-soaking appeared. Bacterial suspensions (about $10^{6} \mathrm{CFU}$ per $\mathrm{ml}$ ) were applied to the first fully expanded trifoliate leaves (about 20 days old). Plants were observed daily for development of symptoms. Bacterial populations in leaves were monitored by punching 15 discs ( $7 \mathrm{~mm}$ in diameter) from the inoculated leaf area 7 days after inoculation. The discs were homogenized in $15 \mathrm{ml}$ of isotonic $\mathrm{NaCl}$ and serially diluted for plating onto King's medium B (10).

Nucleotide sequence accession numbers. The reported nucleotide sequences were deposited with GenBank and EMBL under accession numbers AF101057 (P. syringae pv. glycinea 7a/90), AF101058 ( $P$. syringae pv. phaseolicola GSPB669), AF101059 ( $P$. syringae pv. cannabina GSPB2553), AF101060 (P. syringae pv. sesami 962), and AF101061 (P. syringae pv. pisi GSPB1206).

TABLE 1. Bacterial strains used in this study

\begin{tabular}{lll}
\hline Species & Strain designation & Source or reference \\
\hline $\begin{array}{l}\text { Pseudomonas syringae pv. } \\
\text { avellanae } \\
\text { cannabina }\end{array}$ & CFBP10963 & L. Gardan \\
dendropanices & GSPB2553 & K. Rudolph \\
garcae & CFBP3226 & L. Gardan \\
glycinea & CFBP1634 & L. Gardan \\
hibisci & $7 \mathrm{a} / 90$ & B. Völksch \\
mellea & CFBP11294 & L. Gardan \\
myricae & CFBP2344 & L. Gardan \\
phaseolicola & CFBP11005 & L. Gardan \\
& 6/0 & (1) \\
pisi & PK2 & (24) \\
& GSPB669 & K. Rudolph \\
& GSPB104 & K. Rudolph \\
& GSPB105 & K. Rudolph \\
& GSPB1206 & K. Rudolph \\
& GSPB1477 & K. Rudolph \\
porri & GSPB1787 & K. Rudolph \\
sesami & PP01 & K. Naumann \\
zizaniae & CFBP1908 & L. Gardan \\
Ralstonia solanacearum & G62 & S. Prathuangwong \\
& CFBP11040 & L. Gardan \\
_60 & GSPB1960 & K. Allen \\
\hline
\end{tabular}

a Collection Francaise de Bacteries Phytopathogenes, Anger, France.

${ }^{\mathrm{b}}$ Göttinger Sammlung Phytopathogener Bakterien, Göttingen, Germany. 


\section{RESULTS}

Ethylene production by cell-free protein extracts. Nagahama et al. (13) reported that cell-free extracts are useful for the determination of 2-oxoglutarate-dependent ethylene production in bacteria. Cell-free protein extracts of the $P$. syringae pvs. cannabina, glycinea, phaseolicola, and sesami showed strong ethylene production using this system (Table 2). In addition, cell-free protein extracts of the ethylene-producing P. syringae pv. pisi GSPB1206 showed 2-oxoglutarate-dependent ethylene formation, but had about 20 -fold lower activity than those of the other $P$. syringae pathovars. $P$. syringae pv. pisi GSPB104 and $R$. solanacearum K60 failed to produce ethylene from 2-oxoglutarate, suggesting that $R$. solanacearum might belong to the group of KMBA-dependent ethylene producers.

Ethylene production and growth kinetics. The kinetics of ethylene production and bacterial growth were determined for $P$. syringae pv. sesami 962, a typical 2-oxoglutarate-dependent ethylene producer, $P$. syringae pv. pisi GSPB1206, and $R$. solanacearum K60 as shown in Figure 1. Ethylene production by $P$. syringae pvs. sesami and pisi was strictly growth associated. The highest rates of ethylene formation were detected in the late exponential phase. In contrast, ethylene synthesis by $R$. solanacearum had its maximum in the early exponential phase.

$P$. syringae pv. sesami had a production rate of about $4 \times 10^{-7} \mathrm{nl}$ of ethylene per h per cell, which was 20 -fold higher than that determined for $P$. syringae pv. pisi (about $2 \times 10^{-8} \mathrm{nl}$ per h per cell) and 200-fold higher than that determined for $R$. solanacearum (about $2 \times 10^{-9} \mathrm{nl}$ per $\mathrm{h}$ per cell). A similar high production rate of about $5 \times 10^{-8} \mathrm{nl}$ per $\mathrm{h}$ per cell was previously reported for strains of $P$. syringae pvs. cannabina, glycinea, and phaseolicola (28).

Southern blot analysis. The efe gene of $P$. syringae pv. phaseolicola PK2 was amplified by DIG-labeled PCR and used as probe for Southern blot hybridization studies under conditions of moderate stringency. Bacterial genomic DNA was digested with EcoRI prior to blotting. The efe probe hybridized to all ethyleneproducing $P$. syringae strains tested (Fig. 2). This result suggested that $P$. syringae pv. pisi GSPB1206 also harbored a gene encoding the EFE. No hybridization signal was observed with DNA from the ethylene-negative $P$. syringae pv. pisi GSPB104. The absence of a hybridization signal from genomic DNA of $R$. solanacearum strains K60 and GSPB1960 was an additional indication that ethylene synthesis by this bacterium apparently occurs via the KMBA pathway.

Nucleotide sequence analysis and comparison. Although $P$. syringae pv. pisi GSPB1206 showed 2-oxoglutarate-dependent ethylene production and hybridized to the efe gene probe, this strain produced 20-fold less ethylene than the other $\mathrm{EFE}^{+} P$. syringae pathovars. To determine whether the decreased ethylene production was a result of mutations within the efe gene, the nucleotide sequences of the efe genes from strains of all five ethylene-producing $P$. syringae pathovars were determined. The efe genes were amplified by PCR using the primer set EFE11/EFE12 and directly

TABLE 2. Rate of ethylene production by cell-free extracts from strains of Pseudomonas syringae pathovars and Ralstonia solanacearum

\begin{tabular}{lcc}
\hline & \multicolumn{2}{c}{ Ethylene production $^{\mathrm{a}}$ (nl/h/mg of protein) } \\
\cline { 2 - 3 } Strains & With 2-oxoglutarate & Without 2-oxoglutarate \\
\hline P. syringae pv. & & \\
cannabina GSPB2553 & $369.2 \pm 32.3$ & $0.4 \pm 0.1$ \\
glycinea 7a/90 & $472.0 \pm 60.1$ & $0.7 \pm 0.2$ \\
phaseolicola GSPB669 & $1,165.7 \pm 95.9$ & $1.3 \pm 0.4$ \\
sesami 962 & $497.3 \pm 40.7$ & $1.1 \pm 0.7$ \\
pisi GSPB1206 & $26.2 \pm 3.1$ & $0.2 \pm 0.1$ \\
pisi GSPB104 & $1.3 \pm 0.4$ & $0.7 \pm 0.3$ \\
R. solanacearum K60 & $1.1 \pm 0.7$ & $0.4 \pm 0.1$ \\
\hline
\end{tabular}

${ }^{a}$ The data are the means and standard errors of five independent determinations. sequenced (GenBank submissions AF101057 to AF101061). The sequences of the open reading frame from $P$. syringae pv. cannabina GSPB2553 and $P$. syringae pv. sesami 962 coincided completely with the sequence from $P$. syringae pv. glycinea $7 \mathrm{a} / 90$, which in turn differed in only two single-base pair substitutions from the previously published efe nucleotide sequence of $P$. syringae pv. phaseolicola PK2 (4), leading to only one change in the amino acid sequence. The nucleotide sequence of the efe gene from $P$. syringae pv. phaseolicola GSPB669 was completely identical to that derived from $P$. syringae pv. phaseolicola PK2. In contrast to the high degree of sequence conservation among the mentioned pathovars, a total of 79 base pair substitutions were found when the efe gene from P. syringae pv. pisi GSPB1206 was compared with that of $P$. syringae pv. glycinea $7 \mathrm{a} / 90$. These substitutions led to 29 changes in the deduced amino acid sequence (Fig. 3). Moreover, the efe gene from $P$. syringae pv. pisi GSPB1206 was found to lack 39 base pairs in the $\mathrm{C}$-terminal region, generating a new
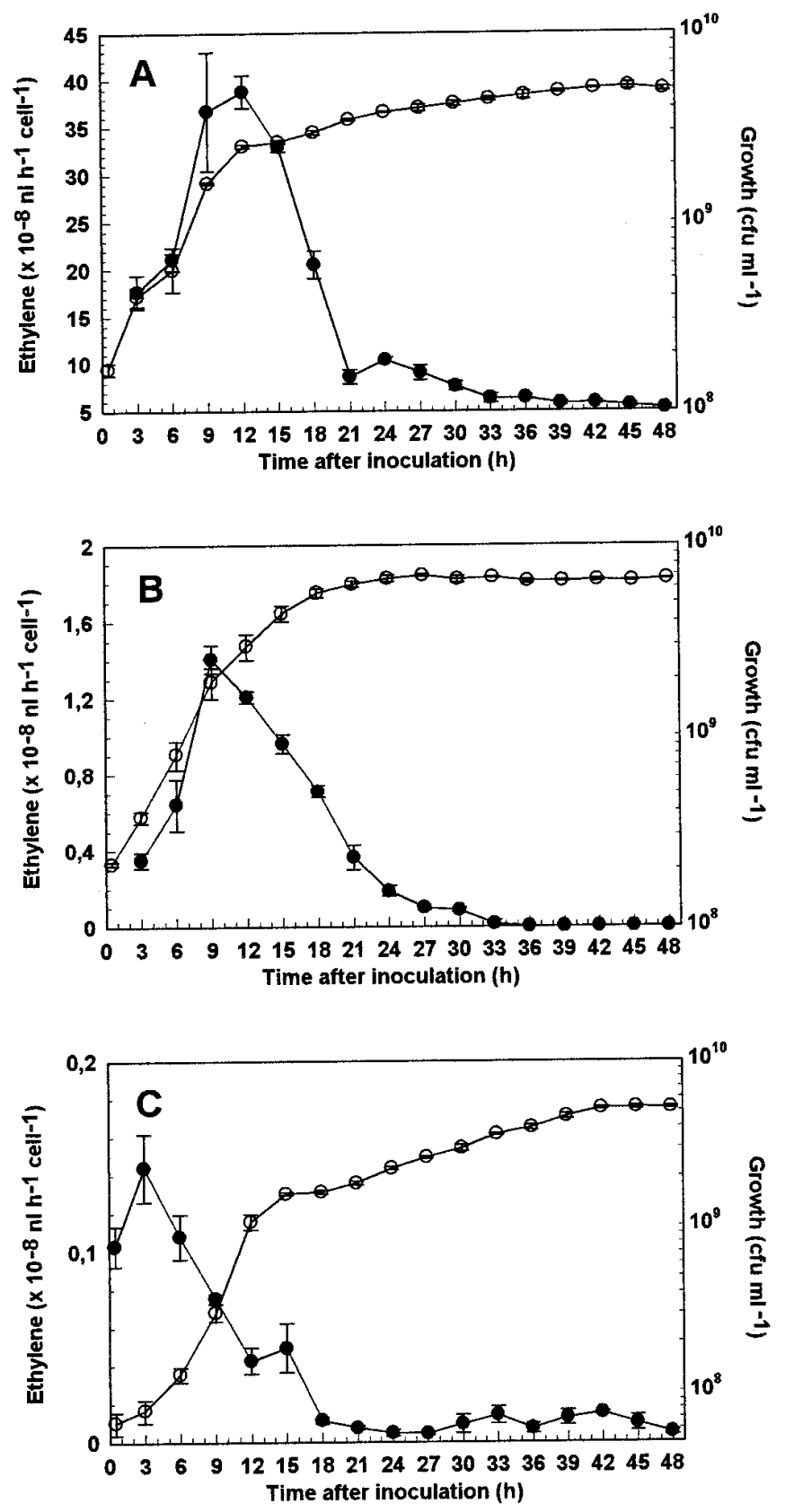

Fig. 1. Growth kinetics $(\mathrm{O})$ and ethylene production $(\bullet)$ by A, Pseudomonas syringae pv. sesami 962 ; B, P. syringae pv. pisi GSPB1206; and C, Ralstonia solanacearum $\mathrm{K} 60$ in shaken cultures. The data are the means and standard errors of three independent experiments. 
stop codon at positions 1,012 to 1,014 (data not shown) and resulting in the loss of 13 amino acids at the C-terminus of the predicted protein (Fig. 3). The nucleotide sequence downstream of the new stop codon differed greatly from nucleotides 1,015 to 1,058 of the efe gene sequence from $P$. syringae pv. glycinea $7 \mathrm{a} / 90$.

Screening for sequence alterations in the efe genes of other $P$. syringae pv. pisi strains. To determine whether the observed nucleotide substitutions in the efe gene of GSPB1206 were characteristic for this pathovar, $P$. syringae pv. pisi strains GSPB105, GSPB1477, GSPB1787, and PP01 were screened for these sequence alterations by PCR. The primer sets EFEP1/EFEP2 and

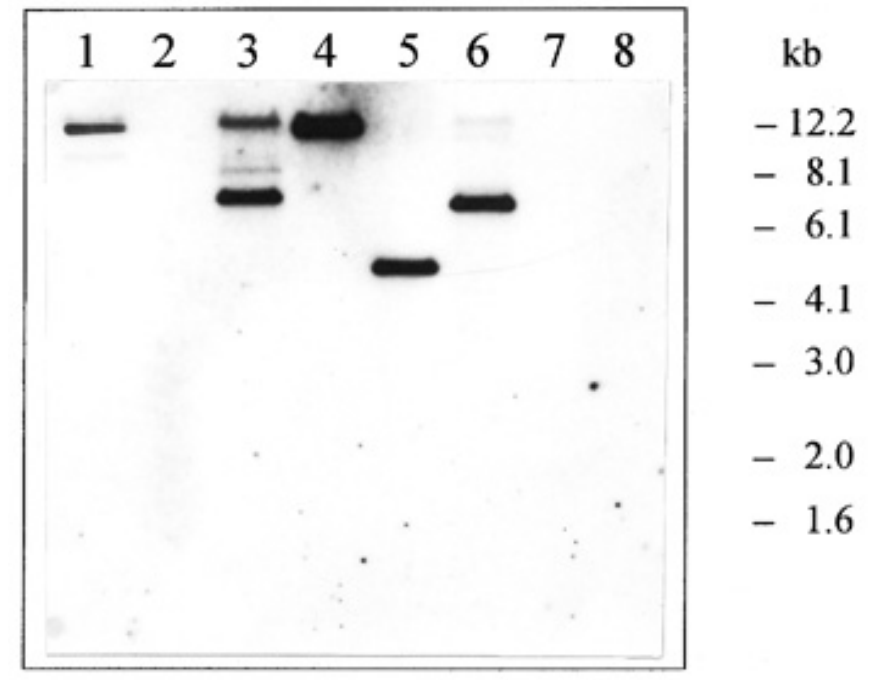

Fig. 2. Southern blot hybridization of EcoRI-digested genomic DNA from Pseudomonas syringae pathovars and Ralstonia solanacearum probed with the efe gene from $P$. syringae pv. phaseolicola PK2. Lane 1, P. syringae pv. pisi GSPB1206; lane 2, P. syringae pv. pisi GSPB104; lane 3, P. syringae pv. glycinea 7a/90; lane 4, P. syringae pv. phaseolicola GSPB669; lane 5, $P$. syringae pv. sesami 962 ; lane 6 , P. syringae pv. cannabina GSPB2553; lane 7, $R$. solanacearum K60; and lane 8, R. solanacearum GSPB1960.
EFEP1/EFEP3 were used to amplify 0.3- and 1-kb DNA fragments, respectively. The sequences of these primers corresponded to DNA regions of the GSPB1206 efe gene, which were significantly divergent from efe sequences derived from other pathovars. Both PCR products were amplified from genomic DNA of all tested $P$. syringae pv. pisi strains, but not from that of representatives of pv. glycinea or pv. phaseolicola (data not shown), indicating that the observed sequence alterations were typical for pv. pisi strains.

Pathogenicity on bean plants. Sato et al. (22) proposed that ethylene production is advantageous for colonization of Leguminosae plants, because the ethylene-producing $P$. syringae pvs. cannabina, glycinea, and phaseolicola can infect plants of this family. In this study, $R$. solanacearum and all ethylene-producing pathovars of $P$. syringae were tested for pathogenicity on bush bean plants (Phaseolus vulgaris) (Table 3 ). We used $P$. syringae pv. phaseolicola $6 / 0$ isolated from bean as a positive control (27). Strains of the $P$. syringae pvs. cannabina, glycinea, and phaseolicola grew very well in the bean plants (Table 3 ). They reached population densities of about $5 \times 10^{7}$ to $2 \times 10^{8} \mathrm{CFU}$ per $\mathrm{cm}^{2}$ of leaf area. Symptoms caused by these pathovars were water-soaked

TABLE 3. Pathogenicity of Ralstonia solanacearum and of the ethyleneforming Pseudomonas syringae pvs. cannabina, glycinea, phaseolicola, pisi, and sesami on bean

\begin{tabular}{|c|c|c|}
\hline Strains & $\begin{array}{c}\text { Bacterial growth } \\
\text { (CFU per } \mathrm{cm}^{2} \text { of leaf area) }\end{array}$ & Symptoms $^{\mathrm{a}}$ \\
\hline $\begin{array}{l}\text { P. syringae pv. } \\
\text { phaseolicola } 6 / 0 \\
\text { (bean strain, control) }\end{array}$ & $2 \times 10^{8}$ & Chlorosis, necrosis \\
\hline cannabina GSPB2553 & $5 \times 10^{7}$ & Chlorosis, weak necrosis \\
\hline glycinea $7 \mathrm{a} / 90$ & $1 \times 10^{8}$ & Chlorosis, weak necrosis \\
\hline $\begin{array}{l}\text { phaseolicola GSPB669 } \\
\text { (kudzu strain) }\end{array}$ & $2 \times 10^{8}$ & Chlorosis, strong necrosis \\
\hline sesami 962 & $5 \times 10^{5}$ & Chlorosis \\
\hline pisi GSPB1206 & $1 \times 10^{6}$ & Chlorosis, weak necrosis \\
\hline R. solanacearum $\mathrm{K} 60$ & $3 \times 10^{3}$ & None \\
\hline
\end{tabular}

${ }^{a}$ Determined 7 days after inoculation.

$\mathrm{b}$ The data are the means of three independent determinations.

7a/90 M T N L T F E L P T EVTGCA A D I S L GRAII Q A W Q K D G I F Q I K T D S E $Q D 45$ 1206 M T N Q T F E I T EVIG S A A D I S I GRAI I Q A W Q K D G I L Q I K T D S E $Q$ N

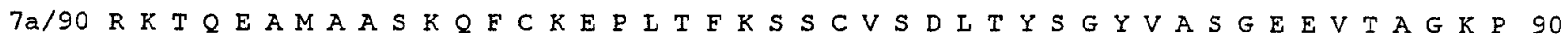
1206 R K TEAMAASKQFCKEPLTEKSSCVS DLTYSGYVASGEEVTAGKR 90

7a/90 D F P E I F T V C K D I S G D Q R V K A GW P C H G P V P W P N N T Y Q K S M K T F M E 135 1206 D F P E I F T V C K D L R V S D Q R V K A GW P C H G P V P W P N N T Y Q K S M K A F M G 135

7a/90 E L G L A G E L L K L T A L G E E L P I N T F T D L T R D GWH H M R V L R F P P $Q$ T S 180 1206 ELGLAGERIIKLTALGF EL P I N T F T D L T R N G W H H M R V I R F P P $Q$ T S 180

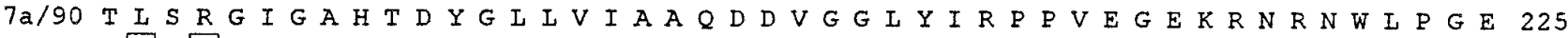

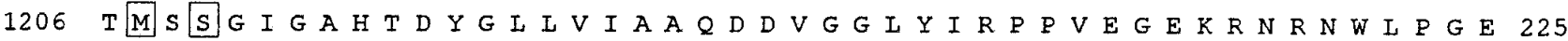

$7 a / 90 S S A G M F E H D E P W T F V T P T P G V W T V F P G D I I Q F M T G G Q I L S T P H K V 270$ 1206 S S A G M F E H D D P W T Y T P V Q N V W T V F P G D I L Q F M T C G Q I I S T P H K V 270

$7 a / 90$ KLN TRER F A C A Y F H E P N FEASAYPLAEPSANERIHYGEH F T M F M 315 1206 L N T R E R F A C A Y F H E P N F E A C A Y Q V F E P S G N E R I H Y G E H F T S M F M 315

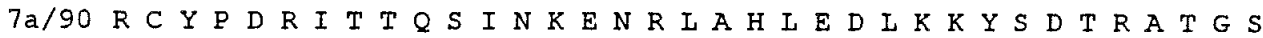

1206 R C Y P D R I T T K I H K D R L A H F R 
lesions that turned chlorotic and then necrotic after 7 days. $P$. syringae pv. phaseolicola strains from kudzu caused very intensive chlorosis that turned into necrotic lesions surrounded by yellow halos. Following inoculation of the bean plants with $P$. syringae pvs. pisi and sesami, symptoms appeared that were similar to those induced by the other $P$. syringae pathovars. $P$. syringae pv. pisi GSPB 1206 caused chlorosis that turned to brown and necrotic lesions, whereas the $P$. syringae pv. sesami strain produced only chlorotic spots. The latter two strains reached population densities of only $1 \times 10^{6}$ and $5 \times 10^{5} \mathrm{CFU}$ per $\mathrm{cm}^{2}$ of leaf area, respectively. $R$. solanacearum was not pathogenic on bean plants. After inoculation, the $R$. solanacearum strain did not cause any symptoms and the bacterial population density reached only $3 \times 10^{3} \mathrm{CFU}$ per $\mathrm{cm}^{2}$ of leaf area. These results demonstrated that all five ethyleneproducing $P$. syringae pathovars, but not $R$. solanacearum, were virulent on bean plants.

Screening of additional $\boldsymbol{P}$. syringae pathovars for ethylene production. To reveal the distribution of ethylene production among various pathovars of $P$. syringae, strains of the pvs. avellanae, dendropanices, garcae, hibisci, mellea, myricae, porri, and zizaniae were tested for their ability to produce ethylene. No strains of these pathovars had ever been examined for ethylene production. All tested strains failed to produce detectable amounts of ethylene.

\section{DISCUSSION}

Ethylene production is a widespread characteristic of microorganisms and most synthesize ethylene at low rates via the KMBA pathway (13). In contrast, the most potent ethylene producers utilize the 2-oxoglutarate-dependent pathway; for example, Penicillium digitatum and certain pathovars of $P$. syringae $(5,13)$. In this study, we characterized ethylene production in $P$. syringae pv. pisi GSPB1206, which produced 20-fold less ethylene than other $P$. syringae pathovars, and in $R$. solanacearum K60, which produced only trace amounts of ethylene. We could not detect any EFE activity or an efe gene in $R$. solanacearum. Moreover, ethylene production in $R$. solanacearum was maximal in the early exponential phase in contrast to the $P$. syringae pathovars, in which ethylene production peaked in the late exponential phase. It is, therefore, likely that $R$. solanacearum may utilize the KMBA pathway.

Cell-free protein extracts from P. syringae pv. pisi GSPB1206 produced ethylene from 2-oxoglutarate in an assay for the EFE (14). Additionally, Southern blot analysis demonstrated the presence of an efe gene in this strain. We, therefore, concluded that ethylene formation by $P$. syringae pv. pisi was mediated by the 2oxoglutarate-dependent pathway. This subsequently raised the question of why this $P$. syringae pv. pisi strain produced ethylene at such a low rate. To show whether sequence alterations in the efe gene were responsible for the lower production rate, the nucleotide sequences of the efe gene from strains of all five ethyleneforming $P$. syringae pathovars were determined. Sequence comparisons indicated that the predicted efe gene products of the pvs. cannabina, glycinea, phaseolicola, and sesami were identical, with only a single amino acid difference in the enzyme of $P$. syringae pv. phaseolicola. Obviously, this change did not interfere with the EFE function, since strains of this pathovar produced ethylene very efficiently. In contrast, numerous nucleotide substitutions were found in the efe gene of $P$. syringae pv. pisi. These changes resulted in 29 amino acid substitutions. Additionally, we identified a deletion of 39 nucleotides at the end of the gene, which led to a Cterminal truncation of 13 amino acids for its gene product. It appears very likely that these sequence alterations in the efe gene of $P$. syringae pv. pisi were responsible for the lower efficiency. The observed differences in the efe gene sequence were a typical characteristic of this pathovar as demonstrated by PCR with genomic DNA of four additional pv. pisi strains.
Nagahama et al. (17) individually substituted each of the 10 histidine codons in the efe gene of $P$. syringae pv. phaseolicola PK2 with codons for glutamine, thereby identifying two histidine residues that were essential for iron-binding and catalytic activity. The other site-directed mutations led to lower catalytic activities, demonstrating that single nucleotide substitutions could cause a decrease in the enzymatic activity.

Highly conserved secondary metabolite synthesis-associated gene sequences in different pathovars of $P$. syringae were also found by Sawada et al. (23) when comparing the $\arg K$ genes from phaseolotoxin-producing $P$. syringae pvs. actinidiae and phaseolicola. In contrast, Bereswill et al. (2) sequenced a PCR product of the $c f l$ gene, involved in coronatine synthesis, from different toxin-producing $P$. syringae pathovars and found numerous differences in the nucleotide sequences.

The high conservation of the efe gene sequences among the $P$. syringae pvs. cannabina, glycinea, phaseolicola, and sesami suggests that horizontal gene transfer between these pathovars may have occurred. Recently, Watanabe et al. (29) demonstrated transfer of a plasmid carrying the efe gene from $P$. syringae pv. glycinea to another pathovar of $P$. syringae in vitro. Normander et al. (18) reported that the phylloplane is conducive to conjugative gene transfer. In our study, the ethylene-producing pathovars of $P$. syringae were tested for pathogenicity on a common host. Bush bean plants were chosen for this experiment because $P$. syringae pvs. cannabina, glycinea, and phaseolicola were known to be pathogenic on this plant species (22). Our results demonstrated that pvs. pisi and sesami were also pathogenic on bean plants. However, in contrast to the other ethylene-producing $P$. syringae pathovars, they reached population densities that were two orders of magnitude lower. The efe gene could have been horizontally transferred between these pathovars by conjugation in the phyllosphere when they simultaneously colonized the same host.

One additional aim of this work was to screen previously untested pathovars of $P$. syringae for ethylene production. For the first time, pvs. avellanae, dendropanices, garcae, hibisci, mellea, myricae, porri, and zizaniae were tested for ethylene production, but none of them were able to produce ethylene. Although our current study was limited to only one representative strain from each of these pathovars, previous experience indicated that ethylene production is a stable characteristic in those pathovars that produce it $(22,30)$. The only exception was the low ethylene-producing pv. pisi, in which strain GSPB104 turned out to be ethylene negative (30). In a previous report, ethylene has been found to be produced by all 50 tested strains of $P$. syringae pv. glycinea isolated from plants of various regions (30). P. syringae is currently subdivided into 55 pathovars (31). A total of 51 pathovars has now been tested for the production of ethylene, and to date, only $P$. syringae pvs. cannabina, glycinea, phaseolicola, pisi, and sesami are known to produce ethylene $(9,22,28)$.

In infected leaf tissue, significant amounts of ethylene were produced by strains of $P$. syringae pvs. glycinea and phaseolicola, suggesting a role for ethylene synthesis in the pathogenicity of these bacteria (30) that preferentially infect leaves. In contrast, strains of $P$. syringae pv. pisi, causing bacterial blight of pea, primarily colonize the stem (11). Perhaps, the lower ethylene production by these strains may not have been disadvantageous for disease development in stem tissue. Over time, the randomly mutated efe gene of $P$. syringae pv. pisi might not have been affected by selection pressure. In contrast, foliar pathogens of $P$. syringae may be under selection pressure to maintain high ethylene production rates. To evaluate the role of ethylene in plant-bacteria interactions, further investigations are in progress in our laboratories.

\section{ACKNOWLEDGMENTS}

We thank C. Allen, S. Prathuangwong, L. Gardan, K. Naumann, K. Nishiyama, and K. Rudolph for providing bacterial strains. 


\section{LITERATURE CITED}

1. Arndt, H., Henning, C., Völksch, B., and Fritsche, W. 1989. Beziehung zwischen Virulenz und Phaseolotoxinbildungsvermögen bei verschiedenen Pseudomonas syringae pv. phaseolicola-Stämmen. Arch. Phytopathol. Pflanzenschutz 25:347-357.

2. Bereswill, S., Bugert, P., Völksch, B., Ullrich, M., Bender, C. L., and Geider, K. 1994. Identification and relatedness of coronatine-producing Pseudomonas syringae pathovars by PCR analysis and sequence determination of the amplification products. Appl. Environ. Microbiol. 60:2924-2930.

3. Freebairn, H. T., and Buddenhagen, I. W. 1964. Ethylene production by Pseudomonas solanacearum. Nature 202:313-314.

4. Fukuda, H., Ogawa, T., Ishihara, K., Fujii, T., Nagahama, K., Omata, T., Inoue, Y., Tanase, S., and Morino, Y. 1992. Molecular cloning in Escherichia coli, expression and nucleotide sequence of the gene for the ethylene forming enzyme of Pseudomonas syringae pv. phaseolicola PK2. Biochem. Biophys. Res. Commun. 188:826-832.

5. Fukuda, H., Ogawa, T., and Tanase, S. 1993. Ethylene production by micro-organisms. Pages 275-306 in: Advances in Microbiology and Physiology. Vol. 35. A. H. Rose, ed. Academic Press, New York.

6. Fukuda, H., Ogawa, T., Tazaki, M., Nagahama, K., Fujii, T., Tanase, S., and Morino, Y. 1992. Two reactions are simultaneously catalyzed by a single enzyme: The arginine-dependent simultaneous formation of two products, ethylene and succinate, from 2-oxoglutarate by an enzyme from Pseudomonas syringae. Biochem. Biophys. Res. Commun. 188:483-489.

7. Fukuda, H., Takahashi, M., Fujii, T., Tazaki, M., and Ogawa, T. 1989. An NADH:Fe(III)EDTA oxidoreductase from Cryptococcus albidus: An enzyme involved in ethylene production in vivo? FEMS (Fed. Eur. Microbiol. Soc.) Microbiol. Lett. 60:107-112.

8. Goto, M., and Hyodo, H. 1987. Ethylene production by cell-free extract of the kudzu strain of Pseudomonas syringae pv. phaseolicola. Plant Cell Physiol. 28:405-414.

9. Goto, M., Ishida, Y., Takikawa, Y., and Hyodo, H. 1985. Ethylene production by the kudzu strains of Pseudomonas syringae pv. phaseolicola causing halo blight in Pueraria lobata (Willd.) Ohwi. Plant Cell Physiol. $26: 141-150$

10. King, E. O., Ward, M. K., and Raney, D. E. 1954. Two simple media for the demonstration of pyocyanin and fluorescin. J. Lab. Clin. Med. 44: 301-307.

11. Kleinhempel, H., Naumann, K., and Spaar, D. 1989. Bakterielle Erkrankungen der Kulturpflanzen. Gustav Fischer Verlag, Jena, Germany.

12. Mattoo, A. K., and Suttle, J. C. 1991. The Plant Hormone Ethylene. CRC Press, Boca Raton, FL.

13. Nagahama, K., Ogawa, T., Fujii, T., and Fukuda, H. 1992. Classification of ethylene-producing bacteria in terms of biosynthetic pathways to ethylene. J. Ferment. Bioeng. 73:1-5.

14. Nagahama, K., Ogawa, T., Fujii, T., Tazaki, M., Goto, M., and Fukuda, H. 1991. L-Arginine is essential for the formation in vitro of ethylene by an extract of Pseudomonas syringae. J. Gen. Microbiol. 137:1641-1646.

15. Nagahama, K., Ogawa, T., Fujii, T., Tazaki, M., Tanase, S., Morino, Y., and Fukuda, H. 1991. Purification and properties of an ethylene-forming enzyme from Pseudomonas syringae pv. phaseolicola PK2. J. Gen. Microbiol. 137:2281-2286.

16. Nagahama, K., Yoshino, K., Matsuoka, M., Sato, M., Tanase, S., Ogawa, T., and Fukuda, H. 1994. Ethylene production by strains of the plant- pathogenic bacterium Pseudomonas syringae depends upon the presence of indigenous plasmids carrying homologous genes for the ethyleneforming enzyme. Microbiology 140:2309-2313.

17. Nagahama, K., Yoshino, K., Matsuoka, M., Tanase, S., Ogawa, T., and Fukuda, H. 1998. Site-directed mutagenesis of histidine residues in the ethylene-forming enzyme from Pseudomonas syringae. J. Ferment. Bioeng. 85:255-258.

18. Normander, B., Christensen, B., Molin, S., and Kroer, N. 1998. Effect of bacterial distribution and activity on conjugal gene transfer on the phylloplane of the bush bean (Phaseolus vulgaris). Appl. Environ. Microbiol. 64:1902-1909.

19. Ogawa, T., Takahashi, M., Fujii, T., Tazaki, M., and Fukuda, H. 1990. The role of NADH:Fe(III)EDTA oxidoreductase in ethylene formation from 2-keto-4-methylthiobutyrate. J. Ferment. Bioeng. 69:287-291.

20. Sambrook, J., Fritsch, E. F., and Maniatis, T. 1989. Molecular Cloning: A Laboratory Manual, 2nd ed. Cold Spring Harbor Laboratory Press, Cold Spring Harbor, NY.

21. Sato, M., Urushizaki, S., Nishiyama, K., Sakai, F., and Ota, Y. 1987. Efficient production of ethylene by Pseudomonas syringae pv. glycinea which causes halo blight in soybeans. Agric. Biol. Chem. 51:1177-1178.

22. Sato, M., Watanabe, K., Yazawa, M., Takikawa, Y., and Nishiyama, K. 1997. Detection of new ethylene-producing bacteria, Pseudomonas syringae pvs. cannabina and sesami, by PCR amplification of genes for the ethylene-forming enzyme. Phytopathology 87:1192-1196.

23. Sawada, H., Takeuchi, T., and Matsuda, I. 1997. Comparative analysis of Pseudomonas syringae pv. actinidiae and pv. phaseolicola based on phaseolotoxin-resistant ornithine carbamoyltransferase gene $(\operatorname{argK})$ and 16S-23S rRNA intergenic spacer sequences. Appl. Environ. Microbiol. 63:282-288.

24. Takikawa, Y., Ando, Y., Hamaya, E., Tsuyumu, S., and Goto, M. 1988. Identification of the pathogens responsible for bacteriosis of tea plant occurred in 1983. Ann. Phytopathol. Soc. Jpn. 54:224-228.

25. Ullrich, M., and Bender, C. L. 1994. The biosynthetic gene cluster for coronamic acid, an ethylcyclopropyl amino acid, contains genes homologous to amino acid-activating enzymes and thioesterases. J. Bacteriol. 176:7574-7586.

26. Völksch, B., Laplace, F., and Fritsche, W. 1984. Untersuchungen zur Variabilität der Phaseolotoxinbildung bei Pseudomonas syringae pv. phaseolicola. Zentralbl. Mikrobiol. 139:109-118.

27. Völksch, B., and Weingart, H. 1997. Comparison of ethylene-producing Pseudomonas syringae strains isolated from kudzu (Pueraria lobata) with Pseudomonas syringae pv. phaseolicola and Pseudomonas syringae pv. glycinea. Eur. J. Plant Pathol. 103:795-802.

28. Völksch, B., and Weingart, H. 1998. Toxin production by pathovars of Pseudomonas syringae and their antagonistic activities against epiphytic microorganisms. J. Basic Microbiol. 38:135-145.

29. Watanabe, K., Nagahama, K., and Sato, M. 1998. A conjugative plasmid carrying the efe gene for the ethylene-forming enzyme isolated from Pseudomonas syringae pv. glycinea. Phytopathology 88:1205-1209.

30. Weingart, H., and Völksch, B. 1997. Ethylene production by Pseudomonas syringae pathovars in vitro and in planta. Appl. Environ. Microbiol. 63:156-161.

31. Young, J. M., Saddler, G. S., Takikawa, Y., De Boer, S. H., Vauterin, L., Gardan, L., Gvozdyak, R. I., and Stead, D. E. 1996. Names of plant pathogenic bacteria 1864-1995. Rev. Plant Pathol. 75:721-762. 